\title{
Fostering Students Transversal Competence Through Modification of Flipped Classroom with Experiential Learning Model
}

\author{
Muslihati \\ Department of Guidance and Counseling \\ State University of Malang, Indonesia \\ muslihati.fip@um.ac.id
}

\author{
Henry Praherdhiono \\ Department of Educational Technology \\ State University of Malang, Indonesia \\ henry.praherdhiono.fip@um.ac.id
}

\author{
Ahmad Yusuf Sobri \\ Department of Educational Administration \\ State University of Malang, Indonesia \\ ahmad.yusuf.fip@um.ac.id
}

\begin{abstract}
This article articulate learning innovation to utilize student mastering transversal competence. As capabilities are needed in nowadays and future workplace, these competence will be facilitated through flipped classroom with experiential learning model is a learning strategy that relevan with learning needs and character of the student of State University of Malang as generation Z. This model emphasizes on self-reliance and learning acquisition from real experiences, then later learner could interpret their learning retention in interactive and egalitarian discussions. The characteristics of this learning are consistent with the experiential learning model that aims to facilitate experience-based learning through a meaningful four-stage cycle. Combination of two learning model is an effort to develop innnovative learning strategy in fostering transversal competence for the student of State University of Malang.
\end{abstract}

Key words: transversal competence, career adaptability, flipped classroom, experiential learning

\section{INTRODUCTION}

There are two major challenges for universities in the information era that are implementing good learning strategy for millenial student, and the changing demand of world of work. The challenges has begun to be felt since entering the year 2010 until today. Regarding the learning characteristics of students, $\mathrm{Z}$ generation as native digital citizen have a distinctive learning style, learning interest and utilization of information and communication technology. This challenge will be a new task for universities in further decades.

Wilson and Gerber (2008) recommend four pedagogical "adaptation" to adaptation "to the millenial" "personality": enhanced clarity of both course structure and assignments; student participation in course design; pre-planned measures to reduce stress; and rigorous attention to the ethics of learning. Dede (2005) even long ago has suggested the utilization of information technology as a medium and vehicle of learning that will increase student's passion.

In other words, learning in college must conform to the self-learning characteristics of millennial generation. On the other hand, the demand of the world of work and the business world will be the figure of a competent graduate higher. All of that can be answered by facilitating millennial generation with $21^{\text {st }}$ century competence while also providing solidification of student career readiness through effective learning.

This challenge can be answered by universities by facilitating the development of transversal competence and adaptability of students' careers. It can be done through learning in accordance with the characteristics of student learning and provide pre-career experience that fosters adaptability, career readiness and self-confidence of students build career success in the future.

The dynamics and transformation of the business world and industry requires a very strong adaptability. A very rapidly changing world can be balanced by creative people and able to learn independently. All this becomes a learning challenge in college, especially from the student aspect. All that cannot be separated from the study habits that have been lived from year to year.

Based on the results of preliminary studies on a number of students of Malang State University, it is found that they tend to have learning habits and mindset about learning that is behavioristic rather than constructivist. As an illustration, they prefer to learn by direction rather than independent self-study to develop an idea, in which tasks tend to ask the boundaries of task completion rather than setting targets, and in terms of understanding between concepts and empirical experience, they choose to learn concepts and then look for real example.

These learning habits tend to be less active and have not trained students to think critically and independently. Indeed conventional learning model that is directive, more emphasized lecturer centered by the lecture method perceived the students are less interesting so that the interest and involvement of students to be active in the learning process has not been quite visible. Learning strategy is one of determinants in effective learning and plays important role in the learning process.

It is bridge conveying learning materials as well as the design of the learning process flow (Joyce, Wiel, \& Calhoun 2003; Santrock, 2001). In higher education, learning should facilitate student learning independently. This condition is one of excellence 
point of State University of Malang learning vision. the institution want to utilize student learning in enjoyful process with sustainable learning innovation. Accordance with the vision this project develop learning strategy.

In fact, some of the facilitation of learning in students at the State University of Malang is still often done with traditional learning models. Each learning style has its strong and weak points. To balance different needs of students of higher education, lecturer should provide learning objectives in many different ways and in that way ensure that all learning styles are covered. This can be achieved through group learning and conversational learning.

Group learning is particularly successful if groups consist of different learning styles. We can find that heterogeneous groups accommodating different learning styles learn significantly more than homogenous group consisting of whatever learning style. Yet based on research finding by Muslihati (2012) obtained an illustration that students of Faculty of Education require more learning strategt that encourage student to engage lecture actively.

While Henry (2017) found an important data that the use of technology in the form of e-learning facilities that are managed with peer learning model can increase student learning involvement and facilitate students to achieve learning objectives better that should be facilitate by experiential learning. These finding related to prelemenary study finding through focus group discussion that the students of State University of Malang have some learning need and learning characteristics. They lack of high order thinking excercises experience during learning process in high school. They also need to be guided in problem solving or project based learning.

As a part of whole research and development of learning innovation within life based curriculum, this project designing a combination of flipped classroom and experiential learning that will be implemented in a new subject that is innovation management course. This strategy will modify experiential learning skills practices and exercises. This article is a part of a research project that aims to develop the transverse competence and adaptability of student careers through experiential-based flipped classroom learning.

Along with the spirit of excellence, the learning patterns applied in the Malang State University is expected to develop theoretical mastery and development of sustainable learning ability for students. In order to meet the expectation of excellence and the demands of adjustment with the characteristics of millenial students, it is developed a learning pattern that implements the concept of experiential-based flipped classroom learning to facilitate the improvement of transversal competence in the students as well as strengthening their career adaptability.

This effort is intended to realize the pedagogical adaptation as suggested by Wilson and Gerber (2008) so that the concept of learning of flipped classroom can be developed with direct learning models. As a part of learning innovation development for improving students' transversal competence, this article articulate teoretical review of flipped classroom, experiential learning and its implementation in learning design of innovation management course. The specific aims of this subject is improving students innovation skills trough tranversal competence and career adaptability. Development of transversal competence and career adaptability will be implementer through the flipped classroom strategy by using flipped classroom model combining with experiential learning.

\section{FLIPPED CLASSROOM FOR MILLENIAL STUDENT}

The flipped classroom itself is an instructional strategy and a type of blended learning, also a kind of mixed learning that reverses traditional learning environments through the presentation of learning content that integrates online patterns and activities outside of the classroom with activities in the classroom. In other words, learning by this moves learning activities, including activities traditionally considered to be homework, into the classroom (Bishop \& Verleger, 2013; Wikipedia, 2018).

In traditional learning, learners are given by lectures or classical direct explanations, group discussions, reading and observing and then completing tasks independently or outside the classroom. In a classroom with a traditional style of instruction, individual lessons may be focused on an explanation of content utilizing a lecture-style.

Unlike traditional learning, in flipped classroom student engaged work independently or in small groups. Lecturer also open opportunities for the studenta in class discussion to control the flow of the conversation, under lecturer supervision. Within the flipped classroom, learning materials are studied independently through learning video media and then they make summaries, take notes of key points, make inquiries, discuss online with fellow students, or read relevant references.

They also do the tasks that will be the learning materials and reinforcement in the classroom. Meanwhile, the classroom activities are still done to strengthen the learning outcomes as well as to explain the concepts that are not understood. Learning activities in the classroom can be done through discussion, practice, learning activities and dialogue (Bergman \& Sams, 2014; Lakmal \& Dawson 2015).

In this learning design, student will explores topics both outside of classroom and inside the classroom. They facilitated to take lesson in greater depth and creates meaningful learning opportunities with educational technologies such as online videos on youtube to deliver content outside of the classroom (Lakmal \& Dawson, 2015). As a nature of flipped classrooms in learning design of manajemen innovation course, student will engage with concrete experience, literature analysis, debate or speech presentation, current event discussions, peer reviewing, project-based learning, and skill development or concept practice (Bergmann \& Sams, 2012).

Trough these types of active learning allow for highly differentiated instruction. In that kind learning 
activities, student will explore their meaningful experience on higher-order thinking skills such as problem-finding, collaboration, design and problem solving as students tackle difficult problems, work in groups, research, and construct knowledge with the help of their lecturer and peers (Bennett, et. all, 2013).

The transformation of learning in college also needs to involve the utilization of information technology in accordance with the character of the information age. This project will transform classroom atmosphere that has long been a routine in college learning needs to be developed in active learning. Flipped classrooms have been suggested by many experts because of the many benefits that can be gained by both learners and by instructors.

Davies, Dean, and Ball (2013) recommend this learning because this learning model can develop the ability to learn independently through online media, develop the sensitivity and critical thinking skills as well as the skills of students in utilizing online-based learning media. This strategy is in line with the model of experiential learning, where learners gain experience learning from real experience, usually through reading or video lectures and then continued in classroom learning so students learn intently and interpret the results of previous learning.

A classroom learning experience that aims to understand the digest of knowledge can be done through problem-solving, discussion or debate strategies. Both of these learning models can be integrated so that the learning in college can be more interesting, constructive and train the 21 st century learning skills that millennial need in facing the information age changes.

Learning objective of innovation management course aims to develop learning independence, critical and innovative thinking skills as well as analytical skills and synthesis of information or materials from various learning sources by tracking references relevant to the topic of lectures. Such learning is based on a constructive approach. A classroom learning experience that aims to understand the digest of knowledge can be done through problem-solving, discussion or debate strategies. The main purpose of flipped classroom is to increase students' learning engagement and train them to be skilled in applying concept mastery.

\section{THE ESSENTIAL OF EXPERIENTIAL LEARNING}

Experiential learning (EL) model developed by Kolb (1984), is a learning model that trains learners to realize and understand their experiences, reflect on, build an abstract of their learning outcomes and exercise in an active experimentation. Furthermore, learners are challenged to realize and practice in active experimentation. This model has four cyclical learning process that will facilitate learners gain some indepth lesson (Figure 1).

Experiential learning model provides opportunity for learners to absorb both information experience and learning impression that touches affective aspect through real experience. Lecturers present experience in learning situations in both real experiences that can be seen and perceived directly by the students as well as the real experience symbolically through cinema or images.

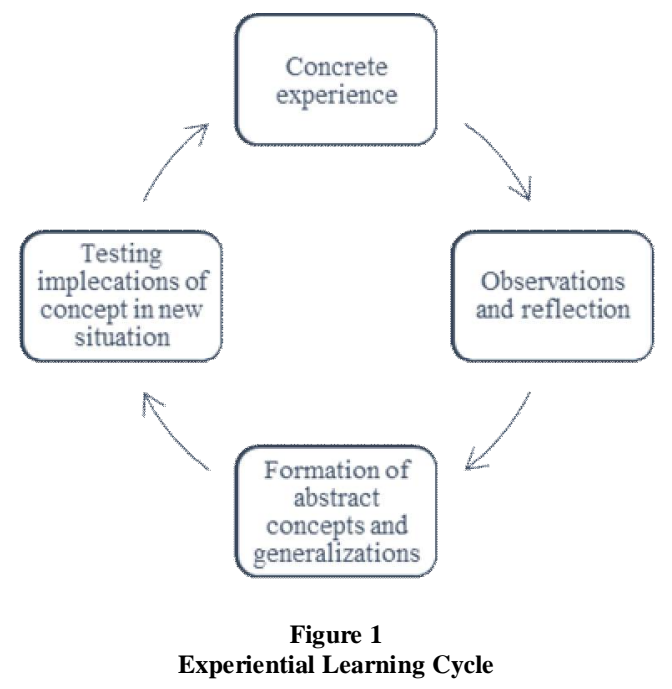

This experience then sees the impact of learning on the psychological structure of students-both cognitive, affective and psychomotor-through reflective observation. This step of reflection on learning outcomes is an important step to foster learners' awareness of their learning outcomes.

Furthermore, the learners will be invited to identify the learning outcomes and formulate them into the conclusions of the learning outcomes. Formulation of notes is very important for learners, because then the impression and memory on the material and learning process will be strengthened. The final step in this model is the implementation stage where learners are challenged to practice their learning outcomes in active experimentation (Kolb, 1999; Warnick, 2014; Sachdeva, 2017).

This model has been examined by some research for many years. During three decade experiential learning facing evolution into a general theory that was accomplished by decoupling it from its roots in a particular social practice and ideology, and then focusing on the concept's technical problems (Kolb, 1999; Seaman, Brown, \& Quay, 2017). However this model still need to be implemented in wider practical and scholarly traditions in order to develop new vocabularies concerning the relationship between experience and learning in higher education programs.

Beard and Wilson (2006) explain that when an individual has experience, it means to be consciously involved in an event, an event or condition that is viewed subjectively. These events touch their feelings and thoughts and then form the knowledge that results from actual observation or from what it does, or as a learning process. The learning process can occur in various contexts of events experienced by a person. Therefore experience is closely related to the learning process. Wilson (in Beard \& Wilson, 2006) defines learning as a relatively permanent change in aspects of 
knowledge, attitudes, and behaviors that occur as a result of formal education or training, or as a result of informal experience.

Learning theory through experience has three philosophical, methodological and theoretical references. This theory is based on the educational philosophy of John Dewey, research method from Lewin and Piaget's cognitive development theory. The three figures have similar views on the learning process. Dewey, Lewin and Piaget view experience as an important learning resource in developing student abilities.

Methodologically Kolb adopted Lewin's "Action Research and Laboratory Training" model which states that learning, change, and growth occur through appreciation of present-and-present experiences. The experience can be meaningful if followed by data collection and observation of experience and data analysis. The results of this data analysis are used to improve knowledge and choose new experiences. These cycles never stop but continue to work.

Philosophically, John Dewey argues that learning is a dialectical process that integrates experience with concepts, observations, and actions. The role of experience as a learning resource was also adopted by Kolb. This philosophical foundation is the spirit of this learning model. While Piaget, Kolb cites the expression that learning is a cycle of interaction between the individual and the environment, with the essential element lies in the beneficial interaction between the concept and reality within a process to the real experience with the process of assimilating the experience of the concept. This philosophical, methodological and theoretical sequence makes this model distinctive among other learning models.

Learning through experience is a holistic theory that defines learning as a major process of human adaptation in its full engagement. For example, learning through experience can be applied not only in the formal education classes but also in all areas of life. The learning process through experience is flexible place and time, always present in every activity wherever and whenever. The holistic nature of the learning process means that the process can occur in various circles from individuals to groups, organizations and society as a whole.

Study studies on this learning model have been implemented worldwide to support the use of this theory across cultures (Kolb \& Kolb, 2009). Learning through experience is not a completely new model. This model evolves over time and has proven to be effective in developing learners' competencies. Learning through experience can be applied to develop new understandings, attitude and skill formation through experience presented in learning.

This learning model aims to integrate theory and practice of learning so that learners get the learning outcomes intact. There are a number of learning methods through experience that enable learners to build their attitudes and values, knowledge and skills through real experience. Students are trained to look critically at these activities through a process of reflection. Then, they gain an understanding some lesson in oral or written form in accordance with the purpose of learning. Experience is used as a catalyst to help learners develop their capacities and abilities.

The works of this model is integrating theory into practice to enable learner achiving learning outcome from experience that has significant role in the individual learning process. The experience presented in learning process is not merely conceptual knowledge but also real experience that will build attitude and skill through tasks that have been systematically designed. In its steps, this method leads learners to analyze, accommodate and formulate learning outcomes.

The experience should be process in reflection and formulation of conceptualization through in dept intepretation. This kind of learning has been widely applied in a variety of settings including, in the field of business, education and clinical. The principles of learning through experience are very useful in the context of formal and non-formal education (Fowler, 2008). In its application this model challenges the learning facilitators (including lecturers, lecturers and trainers) to think about or design learning activities that will be applied to individual participants as well as groups.

Especially since the learning activities focus on student-centered learning process. To apply this learning model, some basic principles need to be understood. Kolb and Kolb (2009) listed six important propositions on the basic principles of learning through experience:

1. Learning is designed as a process, not on results. When applied to a college context, this principle can be useful for improving the quality of learning. Lecturers or facilitators of learning need to involve students in improving the performance and quality of learning through observational reflection and reproduction of learning performance.

2. All learning activities are a re-learning effort. Learning is a processed and systematic activity to describe beliefs and ideas about a topic so it can be tested, tested and integrated with new ideas better.

3. Learning requires conflict resolution between adaptation models to contradictory environments. Conflict, difference and disagreement can control the learning process.

4. Learning is a holistic adaptation process. Learning is not only the result of cognition but the total integrative functioning of the individual, both mind, feeling and perception and behavior.

5. Learning is a synergistic transaction between human and the environment. A stable and longlasting learning pattern grew from a consistent pattern of transactions between individuals and their environment. The interaction of learners with the environment allows them to process knowledge into attitudes and skills. The learning experience of a variety of important events also influences the ability to make choices and make decisions. Therefore, the nature of the individual creates himself through the meaning of learning outcomes from various events in their lives. The learning in 
Kolb's view is in line with the views of constructivism learning theory in which knowledge is created and re-created in the personal knowledge of each learner. This statement is in contrast to the transmission model that has been applied in educational practice, where learners are fed with ideas that have existed and formed long ago. Learning theory through experience aims to facilitate learners to compile their knowledge after passing a learning experience designed in such a way.

Meanwhile, as learning innovation effort within the implementation of life based curriculum at State University of Malang the application of experiential learning, this learning model will be combined with the flipped classroom. The concept of learning aims to foster interest in learning the learners of the information age.

Flipped classroom with experiential learning will deliver in blended learning process which online usincronuos and sincronous learning process followed by inside classroom direct meeting. The learning strategy is aimed to facilitate student matering transversal competence as basic competence to compete in disruption era.

\section{TRANSVERSAL COMPETENCIES FOR GENERATION Z}

Transversal competence is a concept put forward by UNESCO (United Nations Education, Scientific and Cultural Organization), one of the organizations under the auspices of the United Nations. UNESCO places this competency into one of the competencies that are considered to be very supportive to the efforts of achieving the progress of a nation in the information age. This competence is also called 21 st century skills. Transverse competence is essentially a set of capabilities or skills that enable one to develop, adapt, collaborate and succeed in a global context in the 21 st century.

Inkila (2015) calls this competence a prerequisite competence to be a personal innovator. Actually, this competency are not really new. Some aspects of transversal competence are absorbed from several concepts in psychology studies, organizational behavior, nationalism, multicultural relations, critical thinking skills and the ability to utilize information and communication technology. Transversal competence is constructed by UNESCO to provide a direction of competence development that facilitates the readiness for rapid transformation in various fields.

The study of transversal competence itself has not been studied much. However, studies on aspects of transversal competence have been undertaken by many researchers. The studies will complement the transversal competency study building itself. While referring to the academic manuscript of UNESCO research results on transversal competence in education policy and practice (2015). This review discloses conditions and practices in several countries in Asia Pacific. Initially ERI-Net as UNESCO's research implementer composed this competency with four basic parts of skills, abilities, values and attributes. But aspects of transversal competence then evolved into six important aspects.

The six main components of interpersonal skills called UNESCO include intrapersonal skills, media and information literacy, global citizenship, critical and innovative thinking and healthy life competencies physically and psychologically. These six aspects are a series of competencies that are mutually supportive and reinforcing. Initially the UNESCO team determined four aspects of transversal competence: critical and innovative thinking skills, interpersonal skills, intrapersonal skills and global citizenship, but these aspects grew to six following two other aspects: media and information literacy and good health and habits physically and psychologically.

In the process of formulating the construction of the study, UNESCO includes all aspects, but from research results in several countries including Japan, India, Hong Kong, only four aspects that appear consistent existence. In other words terms covered in the sixth and seventh competencies are not widely found or deemed unimportant in countries where UNESCO research is.

Each aspect of transverse competence has the following indicators: (1) interpersonal skills include communication skills, organizational skills, teamwork and collaboration skills, sociability and collegiality, empathy and compassion; (2) intrapersonal skills consist of self-discipline, self-study ability, flexibility and adaptability, self-awareness, perseverance and selfmotivation, compassion, integrity and self-respect; (3) media and information literacy consists of the ethics of the use of information technology, the ability to evaluate information and media content critically, the ability to obtain and analyze information through information and communication technology; (4) global citizenship includes awareness and openness, tolerance and respect for differences, responsibilities and resolving conflicts, understanding of ethics and intercultural relationships, democratic participation, respect for the environment, national identity and love of the country; (5) critical and innovative thinking consists of creativity, entrepreneurship, resourcefulness, applicative ability, reflective thinking, reasoned decision making; and (6) healthy and healthy life skills, both physical and psychological, this ability includes, physical fitness and ability to apply and respect religious values. These competences are really need to reach some attainment and succedd in recent work place. All aspect will be develop as learning materials in innovation management courses.

\section{LEARNING DESIGN OF INNOVATION MANAGEMENT COURSE FOSTERING TRANSVERSAL COMPETENCES}

As mentioned earlier that the learning of innovation management courses will apply experiential learning in flipped classroom. In this course learning will apply flipped learning by applying four experiential learning stages: real experience, reflective observation, abstract conceptualization and active experimentation. Implementing Lee, Morrone and 
Siering (2017) that suggest to all lecturer to organized large class carefully with using active learning and educational technology.

Experiential learning in this research will be developed with a flipped classroom strategy. This learning is done by utilizing multimedia and means of learning indirectly in the form of online course to implement Bishop and Verleger (2013) interpreted the approach of flipped classroom as an educational technique that utilizes online facilities as a medium of learning outside the classroom and followed by a direct meeting in class. To realize the thinking of Dullenbourg (1999) and Hakkinen (1999) that mention about the creation of an active learning space is very urgent. The courses will be develop in active learning process through a collaborative, active, learnercentered pedagogical approach.

Active learning actively involves learners to be active in the process of exploring information and knowledge rather than passively receiving information from lecturers (Prince, 2004). It is not enough to just get there, active learning is also synonymous with collaborative work among students, mutual cooperation, or discussion and teamwork.

According to the students need and theoretical review, innovation management courses objectives are: (1) facilitating students to understand in depth, logical, critical, anticipative, creative, innovative and flexible concepts and strategies to innovate in life so as to be able to face social challenges disruption era; (2) facilitating students to obtain mastery of transversal competence and career adaptability; and (3) facilitating students be able to design career planning and development of innovation plans by utilizing information communication technology responsibly.

The courses will be held in sixteen meetings in online, classroom meeting. in the first meeting, student learning readiness will be prepared by learning skills excercise and brainstorming. The course also have outside classroom using video dan observation real life before courses meeting. Classroom meeting is carried out to facilitate disscussion, collaborative work and other active learning. All experiential learning step will be implemented in the classroom.

\section{REFERENCES}

[1] Beard, C. M., \& Wilson, J. P. 2006. Experiential Learning: A Best Practice Handbook for Educators and Trainers. London. Kogan Page Publishers.

[2] Bennett, B., Spencer, D., Bergmann, J., Cockrum, T., Musallam, R., Sams, A., Fisch, K., \& Overmyer, J. 2013. The Flipped Classroom Manifest.

[3] Bergmann, J., \& Sams, A. 2014. Flip Your Classroom: Reach Every Student in Every Class Every Day. ISBN 1564843157.

[4] Bergmann, J., \& Sams, A. 2012. Flip Your Classroom: Reach Every Student In Every Class Every Day. Washington, DC: International Society for Technology in Education.

[5] Bishop, J. L., \& Verleger, M. A 2013. The Flipped Classroom: A Survey of the Research. Proseeding of 120th Annual Conference and Explotion, American Society for Engineering Education.
[6] Davies, R. S., Dean, D. L., \& Ball, N. 2013. Flipping the Classroom and Instructional Technology Integration in a College-Level Information Systems Spreadsheet Course. Education Tech Research Dev, 61, 563-580.

[7] Dede, C. 2005. Planning for Neomillenials Learning Styles. Educasue Quarterly, 1.

[8] Dillenbourg, P. 1999. What do You Mean by Collaborative Learning? Collaborative-Learning: Cognitive and Computational Approaches. Oxford: Elsevier.

[9] Fowler, J. 2008. Experiential Learning and its Facilitation. Nurse Education Today, 28(4), 427-433.

[10] Hakkinen, P. 2002. Challenges for Design of Computer-based Learning Environments. British Journal of Educational Technology, 33(4), 461-469.

[11] Inkila, M. 2015. Transversal Competencies in the 21st Century School Curricula. Presentation Conducted at the Unitec Research Symposium, Unitec - Mt Albert Campus.

[12] Joyce, B., Weil, M., \& Calhoun, E. 2003. Models of Teaching. Centers for Teaching and Technology - Book Library.

[13] Kolb, A. Y., \& Kolb, D. A. 2009. The Learning Way: Meta Kognitif Aspect of Experiential Learning. Simulation dan Gaming, 40.

[14] Kolb, D.A. 1984. Experiential Learning: Experience as the Source of Learning and Development. Englewood Cllifs, New Jersey.

[15] Kold. D. A, Boyatzis, R. E., \& Mainemelis, C. 1999. Experiential Learning Theory: Previous Research and New Directions. In R. J. Sternberg and L. F. Zhang (Eds.). Perspectives on Cognitive, Learning, and Thinking Styles. NJ: Lawrence Erlbaum.

[16] Lakmal, A., \& Dawson, P. 2015. Motivation and Cognitive Load in the Flipped Classroom: Definition, Rationale and a Call for Research. Higher Education Research \& Development, 34(1), 1-14.

[17] Lee, D., Maorrone, A.S., \& Siering, G. 2018. Swimming Pool To Collaborative Learning Studio: Pedagogy, Space, And Technology In A Large Active Learning Classroom. Education Tech Research Dev, 66, 95-127.

[18] Muslihati. 2012. Aktivitas Pembelajaran Eksperiensial untuk Mengembangkan Kesadaran Multibudaya Calon Konselor (Sebuah Studi Aksi pada Pembelajaran di Perguruan Tinggi). Prosiding Temu Nasional Psikologi Unair, Surabaya, Unair.

[19] Prince, M. 2004. Does Active Learning Work? A Review of the Research. Journal of Engineering Education, 93(3), 223-231.

[20] Santrock, J. W. 2001. Educational Psychology. McGraw-Hill, New York: Apprentissage.

[21] Seaman, J., Brown, M., \& Quay, J. 2017. The Evolution of Experiential Learning Theory: Tracing Lines of Research. Journal of Experiential Education, 40(4).

[22] UNESCO. 2015. Assessment of Transversal Competencies for Use in Education Settings. Retrieved January 12, 2018, from unesdoc.unesco.org/images/0024/002465/246590E.pdf.

[23] Warnick, G. M. 2014. An Experiential Learning Approach to Develop Leadership Competencies in Engineering and Technology Students. Proseeding of $121^{\text {th }}$ Annual Conference and Explotion, American Society for Engineering Education.

[24] Wilson, M., \& Gerber, L. E. 2008. Generational Theory Can Improve How Teachng and Teaching: Strategies for Working with Millenial. Current in Learning, 1(1). 